\title{
Pengembangan Media Audio Visual dan Alat Peraga dalam Meningkatkan Pemahaman Konsep dan Pemecahan Masalah
}

\author{
Fransina Thresiana Nomleni, Theodora Sarlotha Nirmala Manu \\ nomlenifince@gmail.com,piva_mn@yahoo.com \\ Program Studi Pendidikan Biologi, Universitas Kristen Artha Wacana-Kupang

\begin{abstract}
Developing Teaching Material Of The Props Used To Improving The Understanding Of The Concept Of Students
\end{abstract}

\begin{abstract}
The purpose of the research is to produce teaching material of props from scrap materials for system human feasible and practical to be used as a medium of learning in enhancing students' understanding of the concept. The type of research was research and development. ADDIE model used in this reseach contained: 1) Analysis 2) Design 3) Development 4) Implementation and 5) Evaluation. Questionnaire and tests were used as the instruments in data collection. The data analysis in questionnaire forms were statistically using percentage and t test. Pre-test and Post test designed into two groups. Based on the evaluation from the content experts, the value of the material was 82\%, 92.85\% for instructional media, while instructional design was $87.5 \%$. For the small group the media, it reached up to $84.25 \%$, the field pre-experimment group was $87.89 \%$, while the use of user guide was $87.5 \%$, $85 \%$ of instructional media experts, instructional design experts $79.17 \% \%$, the small group bievaluation $84.25 \%$, compared to the experiment group in big number was $86.44 \%$. the result for evaluation of the props materials used were catagorized as excellent. It means $t$-test for the use of teaching material was equal to 3,586 with sig. of $\alpha=0.005, t=$ 2.704. The value of $t$ arithmetic less than t table (3.586> 2.704). It was said that the props of scrap materials improved students' understanding of the concept. The indicator for the concepts include memorizing, understanding, and applied to show that there was increasing in the value of the pre-test and post-test the student.
\end{abstract}

Keywords: props, materials used, the human digestive system, understanding of the concept

Received date: 2 Februari 2018

Article Info

Revised date: 20 Juli 2018
Accepted date: 21 September 2018

\section{PENDAHULUAN}

Media pembelajaran adalah alat batu proses belajar mengajar. Media adalah segala sesuatu yang dapat merangsang pikiran, perasaan, perhatian, dan kemampuan atau keterampilan pelajar sehingga dapat mendorong terjadinya proses belajar pada peserta didik. Menurut Hamalik dalam Arsyad (2007) menyatakan pemakaian media pengajaran dalam proses belajar mengajar dapat membangkitkan keinginan dan minat yang baru, membangkitkan motivasi dan rangsangan kegiatan belajar, bahkan dapat membawa pengaruh kejiwaan terhadap diri siswa. Selain itu menurut Asnawir dan Usman (2002) fungsi penggunaan media pembelajaran adalah memudahkan siswa dalam memahami konsep yang abstrak, membantu guru dalam mengajar dan memberikan pengalaman yang lebih nyata.

Menurut Suprijanto (2009) menyatakan bahwa media audio visual adalah bahan atau alat yang dipergunakan dalam situasi belajar untuk membantu tulisan dan kata yang diucapkan dalam menularkan pengetahuan, sikap dan ide. Terkait dengan menyampaikan pengetahuan diperlukan adanya pemahaman konsep dan pemecahan masalah dari siswa. Selain media audio visual, alat peraga adalah salah satu dari media pembelajaran yang dapat membantu guru dan siswa dalam mencapai tujuan pembelajaran. Alat peraga berperan besar dalam kesuksesan sebuah proses pembelajaran. Penggunaan alat peraga harus dilakukan dengan tepat, demikian juga pemilihan jenisnya yang harus relevan dengan materi pendidikan yang akan dipelajari. Konsep pembelajaran menuntut dua unsur 
yang sama-sama aktif, yaitu siswa dan guru. Keduanya sama berposisi sebagai subjek-objek secara timbal balik.

Alat peraga adalah segala sesuatu yang dapat menyalurkan pesan, dapat merangsang pikiran, perasaan, dan kemauan peserta didik sehingga dapat mendorong terciptanya proses belajar pada diri peserta didik. Adapun Manfaat alat peraga adalah agar belajar lebih cepat bersesuaian antara dalam kelas dan di luar kelas, alat peraga juga memungkinkan mengajar lebih sistematis dan teratur (Faizal, 2010). Alasan menggunakan bahan bekas karena memiliki kelebihan antara lain (1) unik, (2) mudah didapat, (3) tidak memerlukan banyak biaya untuk mendapatkannya atau murah, (4) mengurangi penumpukan sampah, (5) cara kerjanya tidak sulit.

Berdasarkan hasil observasi ditemukan bahwa pemahaman konsep dan kemampuan memecahkan masalah dari sebagian besar siswa terhadap materi sistem pencernaan pada manusia masih rendah. Pemahaman konsep menyangkut dengan pengetahuan (kognitif) antara lain mengingat, memahami, mengaplikasikan masih rendah. Hal ini ditunjukkan dengan pencapaian hasil belajar pada materi sistem pencernaan pada manusia yang belum mencapai KKM (Kriterian Ketuntasan Minimal) Yaitu 75. Dari 20 orang siswa yang mencapai KKM hanya 8 orang saja sedangkan 12 tidak mencapai KKM. Media pembelajaran yang digunakan dalam materi sistem pencernaan manusia menggunakan buku paket dari perpustakaan dan buku pribadi siswa. Alat peraga jarang digunakan oleh guru, dan tidak disiapkan oleh guru. Dalam proses pembelajaran terkadang masih abstrak, sehingga kemampuan siswa dalam memahami masalah, memecahkan masalah, menyelesaikan masalah dan memeriksa kembali penyelesaian masalah yang diberikan oleh guru belum berhasil. Hal ini juga disebabkan karena dalam menyelesaikan masalah diperlukan kemampuan pemahaman konsep sebagai prasyarat dan kemampuan melakukan hubungan antar konsep dan kesiapan secara mental.

Berdasarkan hasil analisis kebutuhan dengan menggunakan angket dan dihitung persentase dari media pembelajaran Audio Visual dan alat peraga materi sistem pencernaan manusia diperoleh $83,33 \%$ siswa setuju dengan penggunaan media pembelajaran audio visual yang menampilkan gambar bergerak dan suara dalam pembelajaran karena pada pembelajaran selama ini menggunakan media pembelajaran berupa buku paket yang berisikan materi dan gambar diam saja. Pada sekolah ini sudah tersedianya sarana prasarana, seperti laboratorium komputer yang dapat dimanfaatkan sebagai penunjang dalam proses pembelajaran IPA Terpadu yang lebih kreatif, khususnya materi pembelajaran sistem pencernaan manusia. $96 \%$ siswa mengatakan setuju dengan pengembangan alat peraga dari bahan bekas dengan alasan bahwa alat peraga dari bahan bekas bisa mengatasi kesulitan belajar yang siswa alami.

Tujuan dari penelitian ini adalah untuk menghasilkan produk pengembangan media pembelajaran audio visual (teks, gambar, video, gerak) dan alat peraga berbahan bekas pada materi sistem pencernaan manusia pada pembelajaran IPA Terpadu dalam meningkatkan pemahaman konsep dan pemecahan masalah serta dapat dijadikan sebagai media atau sumber belajar bagi siswa

\section{KAJIAN PUSTAKA}

Media audio visual adalah media yang mampu merangsang indera penglihatan dan indra pendengaran secara bersama-sama, karena media ini mempunyai unsur suara dan unsur gambar (Djamarah, 2006). Menurut Harmawan (dalam Herlina, 2012) mengemukakan bahwa media audio visual adalah media instruksional moderen yang sesuai dengan perkembangan zaman (kemajuan ilmu pengetahuan dan teknologi) meliputi media yang dapat dilihat dan didengar. Manfaat Penggunaan Media Audio Visual menurut Arsyad (2007) antara lain: Memperjelas penyajian pesan agar tidak terlalu bersifat verbalistis, mengatasi keterbatasan ruang, waktu dan daya indera, dengan menggunakan media pembelajaran secara tepat dan bervariasi dapat diatasi sikap pasif anak didik, dengan sifat yang unik pada setiap siswa, ditambah lagi dengan lingkungan dan pengalaman yang berbeda, sedangkan kurikulum dan materi pembelajaran ditentukan sama untuk setiap siswa, maka guru akan banyak mengalami kesulitan bilamana semuanya itu harus diatasi sendiri.

Menurut Sanaki (2011) menyatakan bahwa beberapa kelebihan media Audio Visual sebagai berikut: menyajikan objek belajar secara konkret atau pesan pembelajaran secara realistik, sehingga sangat baik untuk menambah pengalaman belajar, sifatnya yang Audio Visual, sehingga memeiliki daya tarik tersendiri dan dapat menjadi pemacu atau memotifasi pembelajar untuk belajar, sangat baik untuk pencapaian tujuan belajar psikomotorik, dapat mengurangi kejenuhan belajar, terutama jika 
dikombinasikan dengan teknik mengajar secara ceramah dan diskusi persoalan yang ditanyakan, menambah daya tahan ingatan atau retensi tentang objek belajar yang dipelajari pembelajar.

Meskipun banyak kelebihannya namun media ini juga mempunyai kelemahan yang perlu diperhatikan yaitu:

a. Penggandaanya memerlukan biaya mahal.

b. Tergantung pada energi listrik, sehingga tidak dapat dihidupkan disegala tempat.

c. Sifat komunikasi searah, sehingga tidak dapat memberi peluang untuk terjadinya umpan balik.

d. Mudah tergoda untuk menayangkan kaset CD yang bersifat hiburan, sehingga suasana belajar menjadi terganggu

Model Pengembangan Lee \& Diana Owens terdiri atas:

1. Assessment/ Analisis

Lee \& Owens membagi tahap ini menjadi 2 bagian yakni Assessment kebutuhan dan analisis Front-end. Assessment kebutuhan berfokus pada perbandingan kondisi yang diinginkan/diharapkan. Sedangkan analisis Front-end berfokus pada analis untuk memperkecil gap (hasil dari Assessment kebutuhan) tersebut.

2. Desain

Tahapan ini berisikan 5 langkah kerja sebagai berikut : (a) membuat jadwal proses desain; (b) membuat tim proyek; (c) menentukan spesifikasi media; (d) menentukan isi materi/ outline; (e) melakukan review.

3. Pengembangan

Tahap pengembangan meliputi: (1) membuat story board; (2) produksi; (3) tes produk (review bila perlu)

4. Implementasi

Tahapan ini tidak dijelaskan secara spesifik oleh Lee \& Owens, dan dirangkai dengan tahapan pengembangan.

5. Evaluasi

Pada tahap ini Lee \& Owens lebih banyak membahas evaluasi sumatif, sementara evaluasi formatif dianggap telah dilakukan dalam tahap desain maupun tahapan pengembangan. Tahap evaluasi yang digunakan dalam pengembangan ini adalah evaluasi formatif karena keterbatasan waktu sehingga evaluasi sumatif tidak dapat dilakukan.

Alat peraga adalah semua atau segala sesuatu yang bisa digunakan dan dapat dimanfaatkan untuk menjelaskan konsep-konsep pembelajaran dari materi yang bersifat abstrak atau kurang jelas menjadi nyata dan jelas sehingga dapat merangsang pikiran, perasaan, perhatian serta minat para siswa yang menjurus ke arah terjadinya proses belajar mengajar (Wahidmurni, 2010). Alat peraga juga merupakan suatu alat yang dipakai untuk membntu dalam proses belajar-mengajar yang berperan besar sebagai pendukung kegiatan belajar-mengajar yang dilakukan oleh pengajar atau guru. Penggunaan alat peraga ini bertujuan untuk memberikan wujud yang riil terhadap bahan yang dibicarakan dalam materi pembelajaran. Alat peraga yang dipakai dalam proses belajar-mengajar dalam garis besarnya memiliki manfaat menambahkan kegiatan belajar para siswa, menghemat waktu belajar, memberikan alasan yang wajar untuk belajar, sebab dapat membangkitkan minat perhatian dan aktivitas para siswa.

Adapun tujuan alat peraga menurut Sukarsih (2002:79 dalam Rahmawan 2015) sebagai berikut: agar proses belajar mengajar yang sedang berlangsung dapat berjalan dengan tepat guna dan berdaya guna, untuk mempermudah bagi guru/pendidik daiam menyampaikan informasi materi kepada anak didik, untuk mempermudah bagi anak didik dalam menyerap atau menerima serta memahami materi yang telah disampaikan oleh guru/pendidik, untuk dapat mendorong keinginan anak didik untuk mengetahui lebih banyak dan mendalam tentang materi atau pesan yang disampaikan oleh guru/pendidik, untuk menghindarkan salah pengertian atau salah paham antara anak didik yang satu dengan yang lain terhadap materi atau pesan yang disampaikan oleh guru/pendidik. Sedangkan menurut Sudjana, dkk. (2002:2 dalam Oviana 2011) menyatakan tujuan alat peraga adalah : Pengajaran akan lebih menarik perhatian siswa sehingga dapat menimbulkan motivasi, bahan pelajaran akan lebih jelas maknanya sehingga dapat lebih dipahami, metode mengajar akan lebih bervariasi, dan siswa akan lebih banyak melakukan kegiatan belajar atau siswa akan lebih aktif dalam kegiatan belajar mengajar. 
Pemahaman konsep merupakan tingkatan hasil belajar siswa sehingga dapat mendefinisikan atau menjelaskan sebagian atau mendefinisikan bahan pelajaran dengan menggunakan kalimat sendiri. Menurut teori Taksonomi Bloom Oleh Anderson bahwa dalam dimensi proses kognitif ada beberapa kategori yaitu: mengingat, memahami, mengaplikasikan, menganalisis, mengevaluasi dan mencipta. Indikator pemahaman konsep antara lain: menafsirkan, mencontohkan, mengklasifikasikan, merangkum, menyimpulkan, membandingkan dan menjelaskan.

Adapun faktor-faktor yang dapat mempengaruhi tingkat pemahaman siswa terhadap materi ajar secara garis besar ada dua faktor, yaitu faktor internal dan faktor eksternal (Depag RI: 2001). Faktor internal yaitu faktor yang berasal dari dalam diri siswa itu sendiri, misalnya kematangan berpikir, kesiapan belajar dan motivasi. Faktor eksternal yaitu faktor yang berasal dari luar diri peserta didik, misalnya perencanaan proses pembelajaran, strategi, media serta metode pembelajaran yang digunakan.

Kemampuan pemecahan masalah merupakan suatu proses untuk mengatasi kesulitan yang dihadapi untuk mencapai suatu tujuan yang hendak dicapai. Dalam dunia pendidikan khususnya siswa, mereka akan menghadapi masalah jika materi pembelajaran dengan soal atau pertanyaan yang berkaitan dengan kehidupan sehari-hari. Pertanyaan tersebut menjadi maslah bagi siswa apabila pertanyaan itu harus dipahami dan merupakan tantangan yang harus dipecahkan namun mereka sulit untuk memecahkan masalah. Kemampuan pemecahan masalah adalah kemampuan peserta didik untuk menyelesaikan pertanyaan yang menantang yang tidak dapat dipecahkan oleh prosedur rutin yang sudah diketahui peserta didik.

Menurut Ruseffendi (Saputra, 2012) menyatakan suatu persoalan itu merupakan masalah bagi seseorang jika: (1) persoalan itu tidak dikenalnya, maksudnya ialah siswa belum memiliki prosedur tertentu untuk menyelesaikannya, (2) siswa harus mampu menyelesaikan, baik kesiapan mental maupun pengetahuan, terlepas dari apakah ia sampai atau tidak pada jawabannya, dan (3) sesuatu merupakan permasalahan baginya, bila ia ada niat untuk menyelesaikannya. Menurut Polya (Suherman, 2002) ada empat langkah yang harus dilakukan untuk memecahkan masalah yaitu: (1) memahami masalah, (2) merencanakan pemecahan masalah, (3) menyelesaikan masalah sesuai rencana yang telah direncanakan, (4) memeriksa kembali hasil yang peroleh (looking back).

Kemampuan pemecahan masalah terutama sangat dibutuhkan oleh siswa untuk menyelesaikan berbagai macam soal yang diberikan oleh guru. Siswa harus berpikir kritis, logis, dan kreatif untuk memecahkan masalah dalam soal-soal tersebut. Menurut Makmun dalam Rahayu (2008) menjelaskan bahwa dalam belajar memecahkan msalah siswa dihadapkan pada berbagai pemecahan yang akan membuatnya berusaha untuk menggunakan serta menghubungkan pengetahuanpengetahuan yang telah dimilikinya. Namun dalam memecahkan masalah bukan sekedar menerapkan aturan-aturan yang diketahui, tetapi juga menghasilkan pelajaran baru, dalam memecahkan masalah siswa harus berpikir, mencoba hipotesis dan bila berhasil memecahkan masalah itu ia mempelajari sesuatu yang baru.

Prosedur dalam pemecahan telah dijelaskan Rebori dalam Rahayu (2008:10) sebagai berikut: 1. Menemukan adanya masalah. Ketika seseorang mampu menggambarkan masalah, ia akan mengetahui situasi yang sebenarnya berdasarkan fakta yang ia temukan. 2. Mengidentifikasi dan menemukan penyebab utama dari suatu masalah. Untuk dapat memecahkan suatu masalah diperlukan kemampuan identifikasi dan kemampuan menganalisis penyebab dari permasalahan tersebut. 3 . Menghasilkan beberapa alternatif solusi. Pada tahapan ini dihasilkan lebih dari satu solusi yang dapat digunakan untuk memecahkan masalah. 4. Menentukan alternatif solusi. Setelah didapatkan beberapa solusi alternatif, kemudian dipilih solusi terbaik untuk memecahkan masalah. 5. Mengembangkan suatu rencana tindakan. Perencanaan tindakan dilakukan untuk mengetahui keefektifan dari solusi yang dipilih. 6. Penerapan. Setelah membuat perencanaan tindakan, dilakukan penerapan solusi yang dipilih untuk memecahkan permasalahan yang dihadapi. Apabila siswa telah memahami strategi, prosedur serta langkah-langkah dalam pemecahan masalah maka diharapkan siswa memiliki kemampuan pemecahan masalah dengan baik.

Kemampuan pemecahan masalah akan membantu siswa dalam menguasai berbagai mata pelajaran di sekolah. Sehingga siswa tidak akan merasa kesulitan dalam menerima soal-soal pada mata pelajaran yang membutuhkan kemampuan pemecahan masalah tersebut. Untuk mengukur kemampuan pemecahan masalah siswa maka guru harus memberikan penilaian terhadap kemampuan tersebut. Kemampuan pemecahan masalah dapat dicapai dengan memperhatikan indikator- 
indikatornya sebagai berikut: Kemampuan menunjukkan pemahaman masalah, Kemampuan mengorganisasi data dan memilih informasi yang relevan dalam pemecahan masalah, Kemampuan menyajikan masalah secara matematik dalam berbagai bentuk, Kemampuan memilih pendekatan dan metode pemecahan masalah secara tepat, Kemampuan meningkatkan strategi pemecahan masalah, Kemampuan menyelesaikan masalah yang tidak rutin.

\section{METODE PENELITIAN}

Jenis penelitian adalah Research and Development (R \& D) . Model pengembangan yang digunakan adalah model ADDIE (alat peraga) dan Lee and Owens (media audio visual), penelitian ini berlangsung dari bulan Agustus-Oktober 2017 dan tempat penelitian di SMPN 15 Kupang Tahun ajaran: 2017/2018. Subyek penelitian Siswa kelas VIII A dan Siswa Kelas VIII B yang berjumlah 40 orang. Prosedur pengembangan: 1) Analisis (Analyze) 2) Desain (Design) 3) Pengembangan (Development) 4) Implementasi (Implementation) 5) Evaluasi (Evaluation). Jenis Data adalah jenis data deskriptif kualitatif dan kuantitatif. Teknik pengumpulan data mengunakan angket dan tes untuk pemahaman konsep.

Tabel 1.

Kualitas Skala Penilaian Angket Validasi

\begin{tabular}{|c|c|c|c|}
\hline \multicolumn{4}{|c|}{ SKALA PENILAIAN } \\
\hline 4 & 3 & 2 & 1 \\
\hline Sesuai & Cukup Sesuai & Kurang sesuai & Tidak sesuai \\
\hline Jelas & Cukup jelas & Kurang jelas & Tidak jelas \\
\hline Menarik & Cukup menarik & Kurang menarik & Tidak menarik \\
\hline Mudah & Cukup mudah & Kurang mudah & Tidak mudah \\
\hline Tepat & Cukup tepat & Kurang tepat & Tidak tepat \\
\hline
\end{tabular}

Tabel 2.

Kriteria Interpertasi data

\begin{tabular}{ccc}
\hline Rentangan & Kualifikasi & Keterangan \\
\hline $0 \%-19.99 \%$ & Sangat Tidak Baik & Revisi \\
\hline $20 \%-39.99 \%$ & Tidak Baik & Revisi \\
\hline $40 \%-59.99 \%$ & Cukup Baik atau Netral & Revisi \\
\hline $60 \%-79.99 \%$ & Baik & Tidak Perlu Revisi \\
\hline $80 \%-100 \%$ & Sangat Baik & Tidak Perlu Revisi \\
\hline
\end{tabular}

Teknik analisis data dihitung dengan menggunakan uji t Pre test dan Post test two Group Design. Untuk pemahaman konsep, sedangkan untuk data dari validator dan uji kelompok kecil dan besar analisis data diperoleh melalui angket dalam bentuk persentase. Untuk menguji hipotesis penelitian untuk pemahaman konsep dihitung dengan menggunakan rumus uji t Pre test dan Post test two Group Design .

\section{HASIL PENELITIAN DAN PEMBAHASAN}

\section{Deskripsi Data Penelitian}

Penelitian ini dimulai dari tahap (1) Assesment/analisis di mana dilakukan analisis kebutuhan dengan menggunakan angket, (2) melakukan desain mulai dari materi yang digunakan dan media yang dihasilkan dalam video dan alat peraga kemudian melakukan review, tahap (3) melakukan pengembangan yang meliputi (membuat story board, membuat produk berupa alat peraga dan media audio visual, tahap (4) implentasi yang dilakukan melalui validator/ahli materi, ahli media serta ahli desain dan uji kelompok kecil, kelompok besar dan implentasi di kelas kontrol dan kelas eksperimen dan tahap akhir adalah melakukan evaluasi terhadap implentasi penggunaan produk di kelas. Deskripsi data untuk setiap validator dipaparkan dalam tabel hasil penilaian para ahli/validator dan uji kelompok. Secara ringkas, hasil perhitungan skor pemecahan masalah dalam pelajaran biologi dan pemahaman konsep melalui nilai pree test dan post test pada kelas eksperimen (VIII B) dan kelas kontrol (VIII A) pada SMP Negeri 15 Kota Kupang dapat di lihat pada tabel dan grafik. 


\section{Hasil I}

Berdasarkan hasil yang diperoleh dalam penilaian yang dilakukan oleh para validator/ahli untuk media pembelajaran, desain pembelajaran dan materi terhadap alat peraga diperoleh data yang disajikan pada Tabel 3.

Tabel 3.

Hasil Penilaian Para Ahli

\begin{tabular}{cccc}
\hline No & Ahli/Validator & Persentase (\%) & Petunjuk Pengunaan (\%) \\
\hline $\mathbf{1}$ & Media & $92,85 \%$ & $85 \%$ \\
\hline $\mathbf{2}$ & Desain & $87,5 \%$ & $79,17 \%$ \\
\hline $\mathbf{3}$ & Materi & $82 \%$ & $87,5 \%$ \\
\hline
\end{tabular}

Dari tabel 3 di atas dipaparkan hasil penilaian ahli media terhadap alat peraga sistem pencernaan manusia yang selanjutnya diinterpretasikan maka diperoleh hasil berdasarkan aspek yang dinilai yakni 92,85\%. dengan kualifikasi sangat baik dan tidak perlu direvisi. Hasil penilaian terhadap petunjuk penggunaan alat peraga sistem pencernaan manusia dari bahan bekas dari ahli media yang selanjutnya diinterpretasikan maka diperoleh hasil $85 \%$ yang menunjukan bahwa petunjuk penggunaan berada pada kualifikasi sangat baik dan tidak perlu direvisi.

Berdasarkan hasil penilaian ahli desain pembelajaran terhadap alat peraga dari bahan bekas sistem pencernaan manusia yang selanjutnya diinterpretasikan maka diperoleh hasil berdasarkan aspek yang dinilai diperoleh hasil sebesar $87.5 \%$. Hal tersebut menunjukan bahwa alat peraga dari bahan bekas sistem pencernaan manusia berada dalam kualifikasi sangat baik dan tidak perlu direvisi. Hasil penilaian ahli desain ini didukung oleh penelitian terdahulu oleh Angko (2013), yang mengatakan bahwa persentase keseluruhan aspek oleh para validator mempengaruhi tingkat kelayakan suatu produk pengembangan. Berdasarkan hasil penilaian terhadap petunjuk penggunaan alat peraga sistem pencernaan manusia dari bahan bekas dari ahli desain yang selanjutnya diinterpretasikan maka diperoleh hasil $79,17 \%$ yang menunjukan bahwa petunjuk penggunaan berada pada kualifikasi baik tidak perlu direvisi.

Berdasarkan hasil penilaian ahli materi terhadap materi sistem pencernaan manusia yang mendukung pengembangan alat peraga sistem pencernaan manusia dari bahan bekas yang selanjutnya diinterpretasikan maka diperoleh hasil sebesar $82 \%$. Hal tersebut menunjukan bahwa alat peraga sistem pencernaan manusia dari bahan bekas berada dalam kualifikasi sangat baik dan tidak perlu direvisi. Sesuai dengan hasil penelitian dari Anggraini (2016), bahwa persentase keseluruhan dari ahli materi harus lebih dari $80 \%$ dikatakan layak dan valid untuk digunakan sebagai materi pendukung dari media pembelajaran yang dikembangkan. Berdasarkan hasil penilaian terhadap petunjuk penggunaan terhadap alat peraga sistem pencenaan manusia dari bahan bekas dari ahli selanjutnya diinterpretasikan maka diperoleh hasil $87,5 \%$ yang menunjukan bahwa petunjuk penggunaan berada pada kualifikasi sangat baik tidak perlu direvisi.

\section{Hasil II}

Pada Tabel 4 merupakan paparan interpretasi hasil penilaian hasil uji coba kelompok kecil dan kelompok besar (Responden) terhadap alat peraga yang diperoleh melalui angket.

Tabel 4.

Uji Kelompok Terhadap Alat Peraga

\begin{tabular}{cccc}
\hline No & Kelompok & Persentase (\%) & Petunjuk Pengunaan \\
\hline 1 & Kecil & $84,25 \%$ & $80,75 \%$ \\
\hline 2 & Besar (Responden) & $87,89 \%$ & $82,25 \%$ \\
\hline
\end{tabular}

Hasil perhitungan uji coba kelompok kecil terhadap alat peraga berdasarkan aspek yang dinilai maka diperoleh hasil sebesar $84.25 \%$ sehingga dapat dikatakan alat peraga sistem pencernaan manusia dari bahan bekas sangat layak digunakan sebagai salah satu media pembelajaran bagi peserta didik dalam mata pelajaran IPA Biologi yang mendukung dalam proses pembelajaran. Berdasarkan hasil penilaian terhadap petunjuk penggunaan alat peraga sistem pencernaan manusia dari bahan bekas yang diinterpretasikan maka diperoleh hasil $80,75 \%$ yang menunjukan bahwa petunjuk penggunaan berada pada kualifikasi baik tidak perlu direvisi. 
Dari hasil perhitungan uji coba kelompok besar terhadap alat peraga berdasarkan aspek yang dinilai maka diperoleh hasil $87,89 \%$ sehingga dapat dikatakan bahwa alat peraga sistem pencernaan manusia dari bahan bekas sangat layak digunakan sebagai salah satu media pembelajaran bagi peserta didik dalam mata pelajaran IPA Biologi yang mendukung dalam proses pembelajaran. Berdasarkan hasil penilaian terhadap petunjuk penggunaan alat peraga sistem pencernaan manusia dari bahan bekas selanjutnya diinterprestasikan maka diperoleh hasil 82,25\% yang menunjukkan bahwa petunjuk penggunaan berada pada kualifikasi baik tidak perlu direvisi. Uji kelayakan pada kelompok besar atau uji lapangan adalah tahap akhir dari penelitian pengembangan dan semua uji kelayakan diharuskan mencapai standar presentase di atas $75 \%$ untuk dikatakan layak sebagai media pembelajaran seperti pada penelitian Anung (2012) dengan hasil persentase di atas 75\% baik dari ahli media, ahli desain, ahli materi, uji kelompok kecil dan uji kelompok besar.

\section{Hasil III}

Untuk pemecahan masalah di kelas kontrol disajikan pada Tabel 5 dan untuk kelas eksperimen dapat di lihat pada Tabel 5.

Tabel 5.

Hasil Pemecahan Masalah di Kelas Kontrol

\begin{tabular}{clcccc}
\hline \multirow{2}{*}{ No. } & \multirow{2}{*}{ Indikator Pemecahan masalah } & \multicolumn{2}{c}{$\begin{array}{c}\text { Pertemuan Kelas } \\
\text { Kontrol }\end{array}$} & \multicolumn{2}{c}{$\begin{array}{c}\text { Pertemuan Kelas } \\
\text { Eksperimen }\end{array}$} \\
\cline { 3 - 5 } & & I & II & I & II \\
\hline 1. & Memahami Masalah & $89,28 \%$ & $70,23 \%$ & $92,5 \%$ & $95 \%$ \\
\hline 2. & Memecahkan Masalah & $72,61 \%$ & $79,76 \%$ & $92,5 \%$ & $96,25 \%$ \\
\hline 3. & Menyelesaikan Masalah & $85,71 \%$ & $69,04 \%$ & $71,25 \%$ & $98,75 \%$ \\
\hline 4. & Memeriksa Kembali Penyelesaian & $76,47 \%$ & $71,42 \%$ & $90 \%$ & $98,75 \%$ \\
\hline
\end{tabular}

Hasil analisis untuk pemecahan masalah kelas kontrol rata-rata kemampuan memahami masalah 79,76\%, memecahkan masalah 76,18\%, menyelesaikan masalah 77,37\%, dan kemampuan memeriksa kembali penyelesaian 73,94\%. Sedangkan untuk kelas eksperimen kemampuan memahami masalah 92,25\%, memecahkan masalah 94, 37\%, menyelesaikan masalah $85 \%$ dan kemampuan kembali memeriksa penyelesaian 94,37\%. Sehingga dapat dikatakan bahwa kemapuan memecahkan masalah pada kelas kontrol dan kelas eksperimen berbeda karena pada kelas kontrol tidak mengalami peningkatan sedangkan pada kelas eksperimen mengalami peningkatan.

Berdasarkan data hasil analisis yang telah dilakukan, pada 20 responden di kelas eksperimen yang menggunakan alat peraga untuk pokok bahasan sistem pencernaan pada manusia, ditemukan peningkatan pemahaman konsep yang cukup signifikan. Berdasarkan data dapat dilihat peningkatan hasil Pemahaman Konsep sebesar 29,88 Untuk lebih jelas digambarkan pada Grafik 1

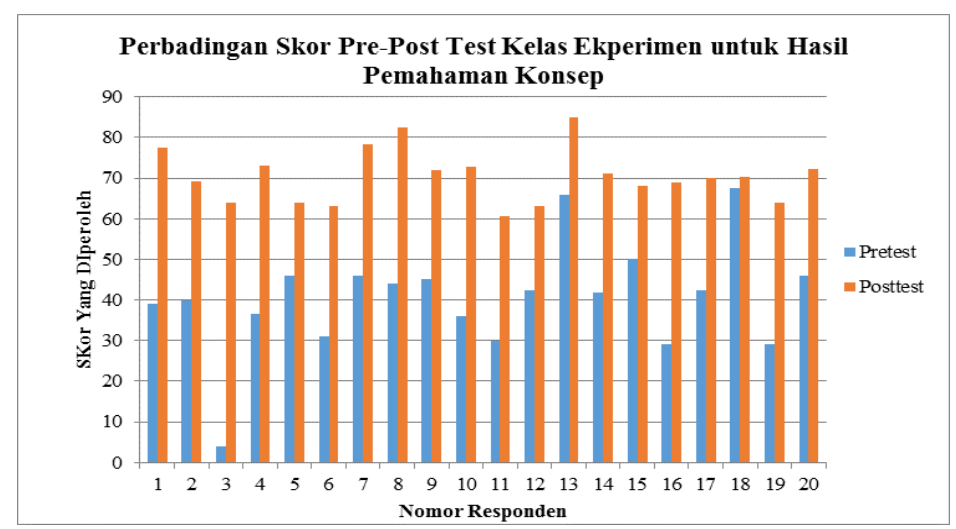

Grafik 1.

Perbandingan hasil Pre test dan Post test di kelas eksperimen 


\section{Analisis Deskriptif Hasil Pre test dan Post test di Kelas kontrol.}

Berdasarkan data hasil analisis yang telah dilakukan, pada 20 responden kelas kontrol yang menggunakan media visual IPA terpadu, ditemukan peningkatan pemahaman Konsep yang cukup signifikan. Berikut adalah hasil rata-rata nilai pemahaman Konsep dari pre test dan post test. Berdasarkan data dapat dilihat peningkatan hasil pemahaman Konsep sebesar 23,06. untuk lebih jelas akan digambarkan pada Grafik 2.

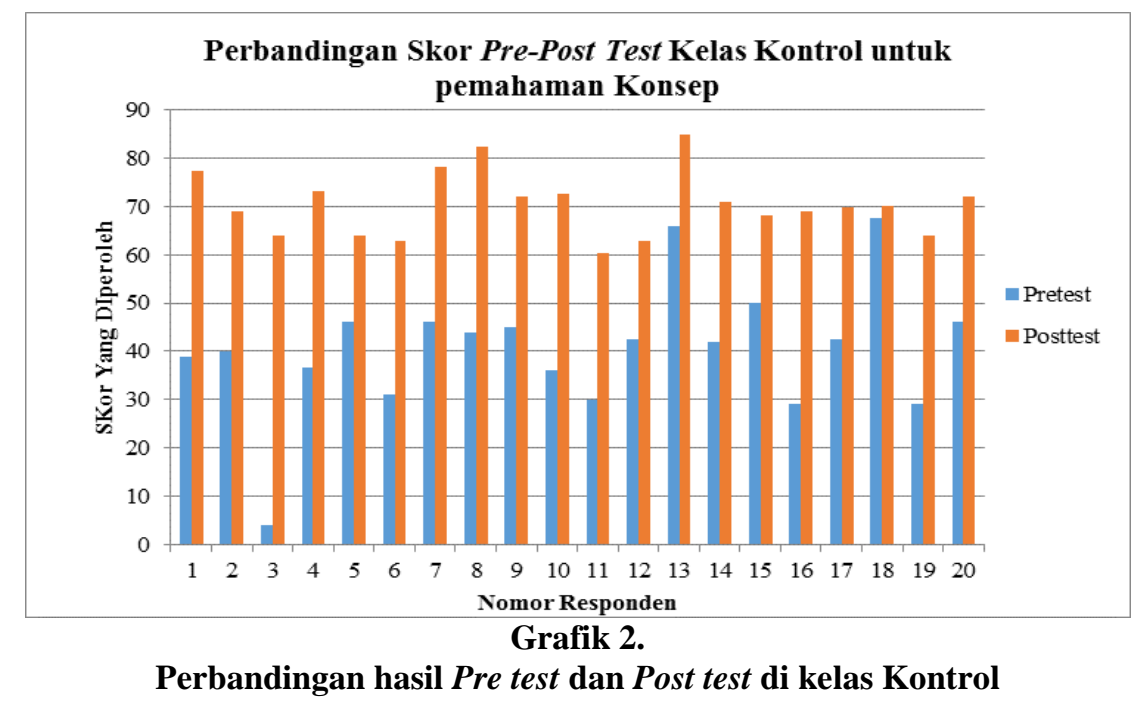

\section{Hasil IV \\ Analisis Uji-t}

Dari perhitungan di atas diperoleh nilat $t$ hitung sebesar 3,586. Untuk mengetahui signifikansi nilai thitung yang di peroleh ini maka perlu dibandingkan dengan nilai t tabel pada tabel $d f$ (degrees of freedom) $=37$, dengan signifikansi $\alpha=0,005$, maka diperoleh nilai t tabel sebesar 2,704. Karena nilai t hitung lebih besar dari nilai $t$ tabel $(3,586>2,704)$. maka dapat dikatakan bahwa media audio visual IPA terpadu dapat meningkatkan pemahaman konsep siswa. Alasan kenapa alat peraga sistem pencernaan manusia dikatakan sangat layak dan valid menurut para validator adalah sesuai dengan penilaian tiap aspek dari masing-masing validator.

Menurut Sudjana (2009 dalam Anung, 2012) alat peraga pendidikan adalah suatu alat yang dapat diserap oleh mata \& telinga dengan tujuan membantu guru agar proses belajar mengajar siswa lebih efektif \& efisien. Alat peraga ini diberikan kepada peserta didik guna memudahkan mereka saat mengikuti proses pembelajaran. Penggunaan alat peraga dapat menambah motivasi belajar siswa sehingga perhatian siswa terhadap materi pembelajaran dapat lebih meningkat. (Sadiman, 2006 dalam Astuti, 2013). Hal ini sesuai dengan penilaian dari ahli materi yang tercantum pada Tabel 4.2 menunjukkan bahwa alat peraga dan media audio visual yang dikembangkan sangat baik atau sangat layak untuk digunakan sebagai bahan ajar dalam proses pembelajaran, dengan 90,18\%. Hal ini didasarkan pada aspek materi yang disusun sesuai dengan tujuan pembelajaran, yaitu penjelasan sistem pencernaan manusia yang ringkas namun memuat poin-poin yang penting sehingga dapat membantu peserta didik dalam memecahkan soal-soal.

Alat Peraga dan media audio visual pembelajaran adalah perantara atau pengantar terjadinya komunikasi dari pengirim menuju penerima. Dengan adanya media pembelajaran dapat menimbulkan semangat belajar siswa sehingga memungkinkan interaksi yang lebih langsung antara siswa dengan siswa, guru dan lingkungan (Priyantini, 2003 dalam Anung, 2012) Hal ini sesuai dengan penilaian dari ahli desain yang tercantum pada Tabel 3 menunjukan bahwa alat peraga dan media audio visual yang dikembangkan baik untuk digunakan sebagai media pembelajaran yang mendukung dalam proses pembelajaran dengan $87.5 \%$. Hal ini didasarkan pada penampilan fisik alat peraga dan media audio visual yang didesain sederhana namun sistematis karena dapat menggambarkan sistem pencernaan manusia secara keseluruhan dan organ-organ pencernaan manusia secara berurutan serta mekanisme kerja dari sistem pencernaan manusia dan terbukti dapat menarik perhatian siswa dalam belajar sehingga peserta didik menjadi aktif dalam kelas. Bahan-bahan yang digunakan pada alat 
peraga pun dapat memberi motivasi pada guru maupun siswa dalam pemanfaatan teknologi murah yang dapat menghasilkan media pembelajaran yang menarik. Hasil uji ahli media yang tercantum pada Tabel 3 menunjukan bahwa alat peraga dan media audio visual yang dikembangkan baik untuk digunakan sebagai media pembelajaran dengan presentase aspek senilai $85 \%$. Hal ini didasarkan pada kesesuaian media belajar yang dikembangkan dengan materi pendukung serta tujuan pembelajaran dan juga penampilan fisik, kecerahan serta pemilihan bahan bekas dalam proses pembuatan yang mudah dipahami.

Hasil penilaian uji coba kelompok kecil yang terantum pada Tabel 4 menunjukan bahwa alat peraga dan media audio visual sistem pencernaan manusia yang dikembangkan sangat baik digunakan sebagai sumber belajar dengan persentase total senilai $86,34 \%$ dengan kualifikasi sangat baik. Hal ini didasarkan penilaian fisik alat peraga dan media audio visual dalam menggambarkan organ pencernaan manusia dari mulut, kerongkongan, lambung, usus halus, usus besar, dan anus serta mekanisme kerja alat peraga mulai dari makanan masuk kedalam mulut hingga proses pembuangan akhir melalui anus. Perpaduan bahan bekas pada alat peraga serta kecerahan warna dapat menarik minat belajar siswa. Selain menarik, kita tidak perlu mengeluarkan banyak biaya dalam proses pembuatan alat peraga.

Penggunaan media yang bervariasi dalam pembelajaran dapat berpengaruh positif terhadap prestasi siswa karna siswa memiliki motivasi yang tinggi dalam belajar sehingga mampu memahami konsep yang diajarkan (Onansanya, 2004 dalam Gupitasari, 2015). Hasil penilaian uji coba kelompok besar yang tercantum pada Tabel 4 diperoleh hasil menunjukan bahwa alat peraga dan media audio visual yang dikembangkan sangat baik untuk digunakan dalam proses pembelajaran dengan $91.831 \%$. Hal ini didasarkan penilaian siswa uji kelompok besar terhadap alat peraga dan media audiao visual yaitu warna pada alat peraga dan media audio visual menarik minat belajar, terdapat organ pencernaan yang dapat menarik minat belajar, serta desain alat peraga yang praktis dan sederhana di dalam maupun di luar ruangan. Pada produk akhir alat peraga dan media audio visual ini, telah di uji oleh validasi ahli (ahli materi dan ahli desain dan ahli media), serta respon siswa uji coba kelompok kecil dan uji kelompok maka didapatkan produk akhir media audio visual dan alat peraga sistem pencernaan manusia dari bahan bekas pada mata pelajaran IPA Biologi yang valid dan layak digunakan siswa dalam proses pembelajaran sebagai media pembelajaran. Ahmed (2005) dalam Anung (2012) berpendapat bahwa sesuai dengan penelitiannya penggunaan media dalam pembelajaran memberikan kontribusi yang berharga bagi kualitas belajar siswa serta hasil belajar siswa.

Berdasarkan hasil penerapan untuk menggunakan alat peraga dan media audio visual didapatkan bahwa ada peningkatan dalam pemahaman konsep di kelas kontrol dan kelas eksperimen. Pemahaman konsep di kelas kontrol peningkatannya sebesar 23,06, sedangkan peningkatan pemahaman konsep di kelas eksperimen adalah 29,88 hal ini menunjukan adanya peningkatan pemahaman konsep yang cukup signifikan siswa melalui penerapan alat peraga dan media audioa visual untuk pokok bahasan sistem pencernaan makanan pada manusia. Pemahaman konsep menyangkut dengan pengetahuan (kognitif) antara lain mengingat, memahami, mengaplikasikan telah ditunjukan bahwa siswa melalui peningkatan nilai pre test dan post test. Terbukti di kelas kontrol dan kelas eksperimen jumlah peningkatan yang di kelas eksperimen lebih besar dari kelas kontrol.

Pemahaman konsep merupakan hal yang sangat diperlukan dalam mencapai hasil belajar yang baik. Siswa dikatakan mempunyai kemampuan pemahaman konsep yang baik apabila mereka dapat menunjukan indikator-indikator pemahaman konsep dalam pembelajaran. Antara lain: menafsirkan, mencontohkan, mengklasifikasikan, merangkum, menyimpulkan, membandingkan dan menjelaskan. Hal ini ditunjang oleh adanya penggunaan alat peraga yang memiliki hubungan dengan materi yang diperlajari. Dalam penelitian ini pemahaman konsep ditunjang dengan alat peraga sehingga adanya peningkatan pemahaman konsep dari siswa. Penelitian mengenai pemahamn konsep juga dilakukan oleh Iwantara, Sadia dan Suma (2014) melalui judul Pengaruh Penggunaan Media Video Youtube dalam Pembelajaran IPA terhadap Motivasi Belajar dan Pemahaman Konsep Siswa. Di mana penelitian mengenai penggunaan media Video memberikan kontribusi terhadap pemahaman konsep siswa.

Kajian mengenai pemahaman konsep juga ditulis oleh Fakhriya, Kuasairi (2010) mengenai pengembangan media pembelajaran IPA Fisika Berbasis Multimedia Flash CS5 Pokok Bahasan Optika Geometri untuk Meningkatkan Pemahaman Konsep Siswa Kelas VIII SMP Negeri 1 
Winongan. Diperoleh bahwa dengan adanya penggunaan media pembelajaran yang dikembangkan mendukung berlangsungnya proses pembelajaran dan pemahaman konsep siswa menjadi lebih baik.

Keterampilan pemecahan masalah pada kelas kontrol diketahui bahwa dalam memecahkan masalah pertemuan I dan II tidak mengalami peningkatan dalam memecahkan masalah hal ini dikarenakan anak-anak merasa jenuh dengan aktivitas yang sama dan tidak ada sumber maupun media pembelajaran yang dapat membantu untuk melancarkan proses pembelajaran. Proses pembelajaran tanpa menggunakan media perantara ini menunjukan adanya penurunan kemampuan memecahkan masalah. Hal ini dapat dilihat bahwa dalam memahami masalah pada pertemuan pertama 89,28\%, pertemuan kedua menurun menjadi 70,23\%. Pada kemampuan memecahkan masalah di pertemuan I diperoleh $72,61 \%$ mengalami peningkatan menjadi 79,76\% dipertemuan II. Untuk kemampuan menyelesaikan masalah di pertemuan I diperoleh hasil $85,71 \%$ mengalami penurunan menjadi 69,04\%. Pada kemampuan memeriksa kembali penyelesaian pada pertemuan I diperoleh $76,74 \%$, sedangkan pertemuan II mengalami penurunan menjadi $74,42 \%$. Dengan metode yang konvensional anak-anak tidak termotivasi dalam melakukan kegiatan pembelajaran, hal ini berbeda dengan kemampuan pemecahan masalah pada kelas eksperimen.

Pada kelas eksperimen terjadi peningkatan untuk kemampuan memecahkan masalah pada pertemuan I dan Ke II. Pada pertemuan I kemampuan memahami masalah adalah 95\% sama halnya dengan perteuan ke II. Kemampuan memecahkan masalah pada pertemuan ke I diperoleh 92,5\% meningkat menjadi 96,25\%. Untuk kemampuan menyelesaikan masalah pada pertemuan I diperoleh $71,25 \%$ mengalami peningkatan pada pertemuan ke II menjadi $98,75 \%$, sedangkan untuk kemampuan memeriksa kembali penyelesaian pada pertemuan I diperoleh $90 \%$ mengalami peningkatan menjadi $98,75 \%$. Hal ini menunjukan bahwa penggunaan video dan alat peraga dalam proses pembelajaran meningkatkan keterampilan dalam memecahkan masalah. Ini dapat dilihat dari memahami masalah, memecahkan, menyelesaikan dan memeriksa kembali penyelesaian masalah mengalami peningkatan. Penggunaan media dan alat peraga ini sangat membantu siswa untuk memahami masalah yang muncul sehingga dapat menyelesaikan dengan memeriksa solusi alternatif pemecahan masalah yang baik.

Dari temuan hasil penelitian ini dapat dikatakan bahwa pengembangan media terhadap kemampuan pemecahan masalah. Temuan ini sejalan/relevan dengan penelitian yang dilakukan Triamini, Marzuki dan Ibrahim (2014) mengenai pengembangan multimedia untuk perolehan belajar pemecahan masalah dalam pembelajaran IPA (Fisika) di Sekolah Menengah Pertama disimpulkan pembelajaran dengan media membuat siswa aktif dan semangat berusaha untuk memecahkan masalah dengan cara yang tepat.

Penelitian mengenai pengembangan media meningkatkan keterampilan pemecahan msalah juga di tulis oleh Firdaus (2017) mengenai Pengembangan Media Pembelajaran Berevisi SETS Berbantuan Komputer untuk meningkatkan keterampilan Pemecahan Masalah relevan dengan penelitian ini di mana peningkatan keterampilan pemecahan masalah siswa yang menggunakan media pembelajaran .

Dengan pembelajaran yang menggunakan media audio visual dan alat peraga yang sederhana dari bahan bekas ini dapat membantu mahasiswa adalah memilih dan mengembangkan pemikirannya dalam memahami masalah, memecahkan, menyelesaikan dan memeriksa kembali penyelesaian masalah secara mandiri, berdiskusi dengan teman kelompoknya, dapat menyalurukan pendapatnya secara optimal dan memabantu siswa dalam bertanggung jawab untuk memeriksa jawabnnya dalam pemahaman sesuai dengan materi pelajaran. Disamping itu juga mendorong siswa untuk lebih berpatisipasi dan lebih aktif dalam kegiatan pembelajaran. Karena akan lebih mudah menemukan dan memahami konsep tentang zat-zat yang dibutuhkan oleh manusia, organ-organ pencernaan makanan, mekanisme pencernaan makanan pada manusia dan ganguan pada organ sistem pencenaan pada manusia. Selain itu proses pembelajaran dilaksanakan dengan lebih menarik sehingga siswa termotivasi dalam mengikuti kegiatan pembelajaran dan memberi dampak pada pemaham konsep dari siswa terhadap materi yang diajarkan. 


\section{SIMPULAN DAN SARAN}

Berdasarkan validasi ahli (ahli materi dan ahli desain dan ahli media), serta respon siswa pada uji coba kelompok kecil dan uji kelompok besar, maka didapatkan produk akhir alat peraga sistem pencernaan manusia dari bahan bekas dan video pembelajaran untuk siswa kelas VIII, dinyatakan valid dan layak digunakan siswa dalam proses pembelajaran sebagai media pembelajaran. Dari perhitungan maka dapat dikatakan bahwa media audio visual dan alat peraga dari bahan bekas dapat meningkatkan pemahaman konsep siswa, dan adanya peningkatkan keterampilan pemecahan masalah.

Saran dari penelitian: bagi Guru: dapat menggunakan media dan alat peraga yang sederhana namun inovatif sehingga dalam kegiatan belajar mengajar menjadi lebih efektif dan efisien; Bagi Siswa: perlu meningkatkan pemahaman konsep dan kemampuan atau keterampilan dalam memecahkan masalah; Bagi para peneliti lainnya: perlu melakukan penelitian lanjutan yang lebih luas di luar variabel penelitian agar dalam bidang pendidikan terus berkembang sehingga meningkatkan mutu pendidikan Indonesia.

\section{UCAPAN TERIMAKASIH}

Ucapan terima kasih ditujukan kepada (1) Pihak Fakultas atas bantuan dana penelitian internal (2) Ucapan terima kasih ditujukan kepada kepala Sekolah SMP N 15 Kota Kupang, (3) ibu Farida selaku guru mata pelajaran Biologi di SMP N 15 Kupang, (4) para mahasiswa yang telah membantu dalam pelaksanaan penelitian ini.

\section{DAFTAR PUSTAKA}

Abdullah, Oviana W,. \& Khatimah H. 2011. " The Use of Model From Scrap Material in Explaining Human Respiratory system”. Jurnal Ilmiah Pendidikan Biologi. 3(2) halaman 51-52.

Abin Syamsuddin Makmun. 2003. Psikologi Pendidikan. Bandung: Rosda Karya Remaja.

Anderson,L. W. \& D. R. Krathwohl (2015). Kerangka Landasan Untuk Pembelajaran, Pengajaran, dan Asesmen Revisi Taksonomi Pendidikan Bloom. Terjemahan : Agung Prihantoro. Yogyakarta :Pustaka Belajar.

Agus Saputra. 2012. Membuat aplikasi Absensi dan Kuisioner untuk panduan Skripsi. PT. ElexMedia Kopuntido: Jakarta.

Anggraini Feranita, 2016. Pengembangan Alat Peraga Sistem Pernapasan Manusia Berbasis Barang Bekas Pada Siswa SMP N 1 Bandar Lampung. Jurnal : Bandar Lampung. FKIP Biologi Lampung.Vol.1, No.1:20-21.

Angko Nancy, 2013. Pengembangan Bahan Ajar Dengan Model ADDIE Untuk Mata Pelajaran Matematika Kelas 5 SDS Mawar Sharon Surabaya. Jurnal : Surabaya. Universitas Negeri Surabaya. Vol.VII, No. 01:18-19.

Anung Nurfa, 2012. Penggunaan Alat Peraga Sistem Pernapasan Manusia Pada Kualitas Belajar siswa SMP kelas VIII. Jurnal : Semarang. Universitas Negeri Semarang. Vol.IV, No.01:8-9.

Astuti Tri, 2013. Pengembangan Media Pembelajaran Kartun 3D Berbasis Muvizu Pada Mata Pelajaran Matematika Kelas I Di SD Lab School UNNES. Jurnal : Semarang. Universitas Negeri Semarang. Vol.V, No.03:22-23.

Asnawir dan Basyiruddin Usman. 2002. Media pembelajaran. Jakarta: Ciputat. Pers.

Azhar Arsyad. 2007. Media Pembelajaran. Jakarta: Raja Grofindo Persada.

Djamarah.2006. Strategi Belajar Mengajar. Jakarta: Rineka Cipta.

Dapertemen agama. 2001. Pola pembelajaran di pesantren. Jakarta. Depag.

Erman Suherman, dkk. 2003. Strategi Pembelajaran Matematika Kontermporer. Bandung: JICA Universitas Pendidikan Indonesia. 
Pengembangan Media Audio Visual dan Alat Peraga dalam Meningkatkan Pemahaman Konsep dan

Pemecahan Masalah (Fransina Thresiana Nomleni, Theodora Sarlotha Nirmala Manu)

Faizal:2010 dalam http://nawawielfatru.blogspot.com/2009/05/keaktifan belajar. html, tanggal 5 Desember 2010).

Fatmawati, L.,Pratiwi, R. D.,\& Erviana, V.Y. (2008). Pengembangan Modul Pendidikan Multikultural Berbasis Karakter Cinta Tanah Air dan Nasionalis pada Pembelajaran Tematik. Sholaria: Jurnal Pendidikan dan Kebudayaan, 8(1).80-92.

Firdaus Firdaus. (2017). Pengembangan Media Pembelajaran Bervisi SETS Berbantuan Komputer untuk Meningkatkan Keterampilan Pemecahan Masalah. Jurnal: Indonesian Journal of Science and Education, 1(1), 17-29.

Gupitasari Dwinorma. 2015. Pengembangan Alat Peraga Destilasi Berbahan Limbah sebagai Implementasi Project Based Learning Guna Meningkatkan Psikomotorik Siwa Dalam Memahami Pemisahan Fraksi Minyak Bumi. Jurnal : Semarang. Jurusan FKIP Kimia Universitas Negeri Semarang. 3 (2), 12-13.

Herlina. 2012. Penerapan Model Pembelajaran Cooperative Learning tipe STAD Sebagai Upaya Meningkatkan Hasil Belajar Siswa Dalam Pembelajaran IPS di Sekolah Dasar. [online] http://repository.upi.edu/skripsiview.php?no_skripsi=13317, diakses tanggaSuprijono. 2009. Cooperative Learning Teori \& Aplikasi Paikem. Yogyakarta : Pustaka Pelajaran 2 April 2016.

Hamalik Oemar. 2001. Prosedur Belajar Mengajar. Jakarta: Bumi Aksara.

Hermawan, Asep Herry. 2007. Pengembangan Kurikulum dan Pembelajaran. Jakarta: Universitas Terbuka.

W. Iwantara, I. W. Sadia, I. K. Suma. (2014). Pengaruh Penggunaan Media Video Yuotube dalam pembelajaran IPA Terhadap Motivasi Belajar dan Pemahaman Konsep Siswa. Jurnal: eJournal Program Pascasarjana Universitas Pendidikan Genesha Program studi IPA. 4. 2014.

Lestari, Tri Arum, Mudzanatun, dan Damayani, Aries Tika. 2017. Keefektifan Media Audio Visual sebagai Kreatifitas Guru Sekolah Dasar dalam Menumbuhkan Keterampilan Menulis Puisi Siswa. Sholaria: Jurnal Pendidikan dan Kebudayaan, 7(3), 214-225.

Nana sudjana dan Ahmad Rivai. 2002. Media Pengajaran. Bandung: Sinar Baru Algesindo.

Nasution. 2010. Berbagai Pendekatan dalam Proses Belajar dan Mengajar. Jakarta: Bumi Aksara.

Riduwan. 2007. Pengantar Statistik Untuk Penelitian Pendidikan, Sosial, Ekonomi, Komunikasi dan Bisnis. Bandung: Alfabeta.

Riwudan. 2012. Dasar-Dasar Statistik. Bandung: Alfabeta.

Sugiyono, 2008. Metode Penelitian Pendidikan Pendekatan Kuantitatif, Kualitatif, Dan R\&D. Bandung: Alfabeta Bandung.

Suharsini Arikunto. 2006. Prosedur Penelitian Suatu Pendekatan Praktek Edisi Revisi. Jakarta: Rineka cipta.

Suprijono, Agus. 2009. Cooperatif Learning (Teori dan Aplikasi PAIKEM). Yogjakarta: Pustaka Pelajar.

Sukarsih, Karti Hari. 2002. Media Pembelajaran dan Jenis-jenis Media Pembelajaran. Jakarta: PT RajaGrafindo Persada.

Sri Rahayu. 2008. Prosedur Penelitian suatu Pendekatan Praktik. Jakarta: Rineka Cipta.

Wahidmurni. 2010. Pembelajran Ilmu Pengetahuan Sosial Terpadu Pada Satuan Pendidikan Mi/S Dan Mts/Smp. Http://Tarbiyah.Uin-Malang.ac.id. Diakses Senin, 12 Nopember 2016 Jam 08.52 .

Yulia Triatmini, H. Marzuki, H. Sutini Ibrahim. (2014). Pengembangan Multimedia untuk Perolehan Belajar Pemecahan Masalah Dalam Pembelajaran IPA (Fisika) di Sekolah Menengah Pertama. Jurnal: Pendidikan dan Pembelajaran. 3(12) 2014 